\title{
Electrochemical Detection of Benzodiazepines, Following Liquid Chromatography, for Applications in Pharmaceutical, Biomedical and Forensic Investigations
}

\section{Kevin C. Honeychurch and John P. Hart ${ }^{*}$}

Centre for Research in Biosciences, University of the West of England, Bristol, BS16 1QY, UK

* Author to whom correspondence should be addressed; E-Mail: john.hart@uwe.ac.uk

Received: 22 October 2013 / Accepted: 21 December 2013 / Published: 23 January 2014

\begin{abstract}
Benzodiazepines are an important class of drugs commonly administered with a potential for abuse and environmental pollution. This review focuses on the liquid chromatographic electrochemical detection of the benzodiazepine class of drugs. These are characterised by a readily electrochemically reducible azomethine group, with a number also substituted by other electrochemically active groups. Liquid chromatography employing both single and dual electrode detection has been reported for a variety of benzodiazepines and their metabolites in biological, pharmaceutical, biomedical and forensic investigations. Recently, electrochemistry has been utilised to mimic biological oxidation processes and has been combined with liquid chromatography/mass spectroscopy for their identification and quantification of the products generated. The present review focuses on recent developments in liquid chromatographic- electrochemical determination of benzodiazepines reported since 2006, with earlier reports given in summary.
\end{abstract}

Keywords: benzodiazepines; liquid chromatography; electrochemical detection; single and dual electrodes; review. 


\section{Introduction:}

Since the discovery in 1955 of the first benzodiazepine drug, chlordiazepoxide hydrochloride (Librium $^{\circledR}$ ) [1], a number of structurally similar benzodiazepines have been synthesised, with about thirty presently in medical use [2]. These are utilised widely as tranquillisers, hypnotics, sedatives, antidepressants, for both humans [2-4] and animals [5], which act by increasing the efficiency of the neurotransmitter $\gamma$-aminobutyric acid (GABA) to decrease the communication between neurons, so calming many of the functions of the brain [2,3].

Many of the pharmaceutically active benzodiazepines are based on the 1,4-benzodiazepine structure shown in Figure 1. Here benzodiazepine refers to the portion of the structure composed of a benzene ring A fused to the seven-membered diazepine ring, B. The majority also have an aryl substituent ring C. The three ring systems are required for the benzodiazepine pharmaceutical activity [6]. The addition of an electron withdrawing group (i.e. $\mathrm{Cl}$ or $\mathrm{NO}_{2}$ ) at the 7 position is optimal for pharmaceutical activity with substitutions at other positions of this ring decreasing activity. The other aryl ring system $\mathrm{C}$ contributes to benzodiazepine-receptor binding through hydrophobic and steric interactions. Again, the type and position of substitutions in this ring affects the activity; an electron withdrawing group at the 2' position increases the benzodiazepine activity, with substitutions at the 4' position decreasing the activity. The diazepine ring system $\mathrm{B}$ is required for optimum receptor binding; the amide or $\mathrm{N}$-alkyl groups contribute to receptor binding, with biological activity increased by the addition of a methyl group at the 1-position, larger groups, such as tert-butyl result in decrease activity [6].

There are a number of other structures based on dibenzo substituted forms, such as, clozapine, an antipsychotic during used in the treatment of schizophrenia and bipolar disorder and nevirapine, a reverse-transcriptase inhibitors, an antiretroviral drug used to treat HIV infection. The ability to readily change the mode and activity of this class of drugs has made them a popular area of pharmaceutical development.

Figure 1. 1,4-benzodiazepine ring systems.

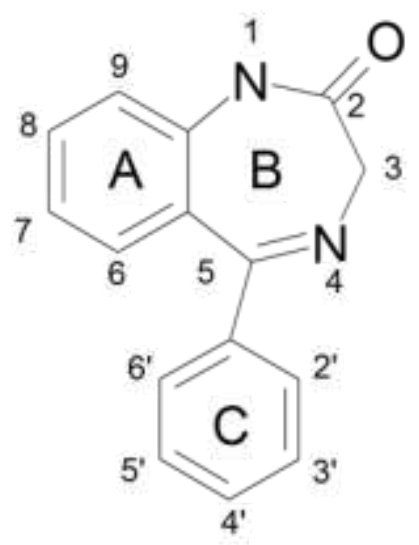


However, for some time there has been a degree of controversy regarding the use of benzodiazepines $[2,3,7,8]$ as prolonged use can result in increased tolerance, physical dependence and withdrawal symptoms; in addition overdoses result in symptoms such as respiratory depression or coma. Reviews $[9,10]$ have highlighted other issues, especially with the elderly, with increased reports of falls and a resulting increased incidence of hip fractures and risk of cerebrovascular events and deaths.

Due to their wide pharmaceutical applications, and subsequent disposal, concern has also arisen regarding other areas effecting the wider population. Reports have highlighted their use in drugfacilitated crime (DFC), drug-facilitated sexual assaults (DFSA) [11-13] and abuse [2,8]. Detectable levels have also been recently reported in potable and environmental water systems, resulting in possible toxic effects for both humans and aquatic life [14-16]. Consequently, there is a pressing demand for methods capable of determining trace levels of benzodiazepines in both environmental and medical biological samples. Common analytical approaches utilised for the determination of benzodiazepines, such as, gas chromatography [17], immunoassay [17-19], liquid chromatography [19-21] and spectroscopy [22] have been reported. However, the application of liquid chromatography with electrochemical detection for the analysis of this group of drugs has not been recently reviewed. In this article we review such developments since 2006.

\section{The Electrochemical Behaviour of Benzodiazepines}

The 1,4-benzodiazepine class of drugs are characterised by a relatively easily reducible azomethine group; a number also contain other electrochemically active groups such as, nitro, $N$-oxide and carbonyl groups. The $2 \mathrm{e}^{-}, 2 \mathrm{H}^{+}$electrochemical reduction of the azomethine group results in the corresponding dihydro derivative (eq. 1) [23].

$$
\mathrm{R}-\mathrm{C}=\mathrm{N}-\mathrm{R}^{\prime}+2 \mathrm{e}^{-}+2 \mathrm{H}^{+} \rightarrow \mathrm{R}-(\mathrm{H}) \mathrm{C}-\mathrm{N}(\mathrm{H})-\mathrm{R}^{\prime}
$$

(eq.1)

Many of the 1,5-benzodiazepines, such as clobazam are reported to be electrochemically inactive [24]. However, some, such as the 3H-1,5-benzodiazepines [25] have been shown to undergo two $2 \mathrm{e}^{-}$, $2 \mathrm{H}^{+}$reductions at their azomethine groups. The dibenzo substituted benzodiazepines such as clozapine (scheme I) undergo a reversible $2 \mathrm{e}^{-}, \mathrm{H}^{+}$redox reaction involving a relatively stable nitrenium ion [26,27].

\section{Scheme I}

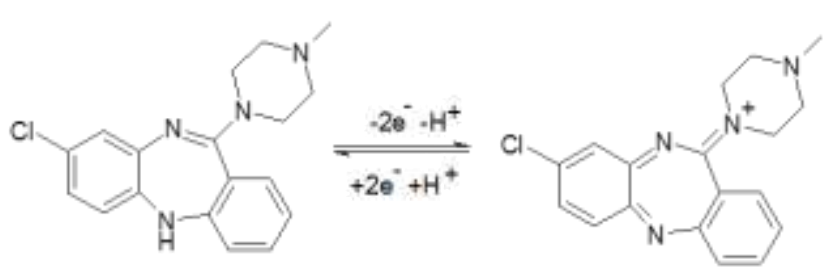




\begin{tabular}{|c|c|c|c|c|c|c|}
\hline $\begin{array}{l}\text { Benzodiazepines } \\
\text { Determined }\end{array}$ & $\begin{array}{l}\text { Mobile and stationary } \\
\text { phase }\end{array}$ & Linear range & $\begin{array}{l}\text { Detection } \\
\text { limit }\end{array}$ & Electrode & Sample & Ref. \\
\hline $\begin{array}{c}\text { Bromazepam, } \\
\text { Lorazepam, } \\
\text { Nitrazepam, } \\
\text { Clonazepam, } \\
\text { Nordiazepam, } \\
\text { Flunitrazepam, } \\
\text { Diazepam, } \\
\text { Temazepam, } \\
\text { Midazolam } \\
\end{array}$ & $\begin{array}{l}0.02 \mathrm{M} \text { phosphate } \\
\text { buffer (pH 6) and } \\
\text { acetonitrile 55:45 } \\
(\mathrm{v} / \mathrm{v}) . \text { LiChrospher- } \\
100 \mathrm{RP}-8 \mathrm{ec} \text { column } \\
(150 \times 4.6 \mathrm{~mm}) .\end{array}$ & $\begin{array}{l}\text { Up to at least } 2 \\
\mathrm{mg} / \mathrm{l} \text { for each } \\
\text { compound. }\end{array}$ & $\begin{array}{l}\text { In the range } \\
\text { of } 6.5-123 \\
\mathrm{ng} / \mathrm{ml}(130 \\
\mathrm{pg}-2.46 \mathrm{ng} \\
\text { on-column) }\end{array}$ & $\begin{array}{l}\text { hanging mercury drop } \\
\text { electrode at }-1.4 \mathrm{~V} \text { (vs. } \\
\mathrm{Ag} / \mathrm{AgCl} \text { ), coupled with } \\
\mathrm{UV} \text { detection at } 250 \mathrm{~nm}\end{array}$ & $\begin{array}{l}\text { Forensic human } \\
\text { blood samples, } \\
\text { following liquid - } \\
\text { liquid extraction } \\
\text { with } \mathrm{CHCl}_{3}\end{array}$ & [31] \\
\hline $\begin{array}{c}\text { Clonazepam, } \\
\text { Diazepam, } \\
\text { Flunitrazepam, } \\
\text { Lorazepam, } \\
\text { Nitrazepam, } \\
\text { Nordiazepam, } \\
\text { Flurazepam, } \\
\text { Oxazepam } \\
\end{array}$ & $\begin{array}{l}0.03 \mathrm{M} \mathrm{pH} 4.6 \text { acetate } \\
\text { buffer and acetonitrile } \\
55: 45(\mathrm{v} / \mathrm{v}) . \\
\mathrm{LiChrospher-100} \mathrm{RP-} \\
8 \mathrm{ec}(150 \times 4.6 \mathrm{~mm})\end{array}$ & $\begin{array}{l}25-200 \mu \mathrm{g} / \mathrm{l} \\
\text { utilising } N- \\
\text { methylclonazep } \\
\text { am as internal } \\
\text { standard }\end{array}$ & $\begin{array}{l}2.0 \text { to } 4.1 \\
\mathrm{ng} / \mathrm{ml}\end{array}$ & $\begin{array}{l}\text { hanging mercury drop } \\
\text { electrode at }-1.4 \mathrm{~V} \text { (vs. } \\
\mathrm{Ag} / \mathrm{AgCl} \text { ), coupled with } \\
\mathrm{UV} \text { detection at } 250 \mathrm{~nm}\end{array}$ & $\begin{array}{l}\text { Forensic human } \\
\text { blood, plasma, } \\
\text { urine and saliva } \\
\text { samples, } \\
\text { following liquid - } \\
\text { liquid extraction } \\
\text { with } \mathrm{CHCl}_{3}\end{array}$ & [32] \\
\hline $\begin{array}{c}7- \\
\text { acetamidonitrazepam, } \\
\text { 7-aminonitrazeapam, } \\
\text { chlordiazepoxide, } \\
\text { demoxepam, } \\
\text { desmethylchlordiazepo } \\
\text { xide, } \\
\text { desmethyldiazepam, } \\
\text { diazepam, lorazepam, } \\
\text { Loprazolam, } \\
\text { nitrazepam, oxazepam, } \\
\text { temazepam, triazolam }\end{array}$ & $\begin{array}{l}\text { Methanol-1-propanol- } \\
\text { aqueous pH } 6.0 \\
\text { phosphate buffer } \\
(100: 7: 5: 80) \text {. CPS- } \\
\text { Hypersil column (100 } \\
\text { x } 4.5 \mathrm{~mm})\end{array}$ & $\begin{array}{l}\text { Nitrazepam } 4.2 \\
-1070 \mathrm{ng} / \mathrm{ml}, 7 \text { - } \\
\text { acetamidonitraz } \\
\text { epam and } 7 \text { - } \\
\text { aminonitrazeapa } \\
\mathrm{m}, 16.7 \text { - } 2140 \\
\mathrm{ng} / \mathrm{ml} \text {. All } \\
\text { others } 8.4- \\
2140 \mathrm{ng} / \mathrm{ml}\end{array}$ & $\begin{array}{l}\text { Range } \\
\text { between 1-5 } \\
\mathrm{ng} / \mathrm{ml}(40- \\
200 \mathrm{pg} \\
\text { injected) }\end{array}$ & $\begin{array}{l}\text { pendent mercury drop } \\
\text { electrode at }-1.2 \mathrm{~V}, \\
\text { preceded by a coulometric } \\
\text { detector fitted with porous } \\
\text { carbon electrodes held at } 0 \\
\mathrm{~V}\end{array}$ & $\begin{array}{l}\text { Blood, diluted } \\
\text { with aqueous } \\
\text { sodium octyl } \\
\text { sulphate to } \\
\text { suppress protein } \\
\text { binding, followed } \\
\text { by microcolumn } \\
\text { clean-up }\end{array}$ & [60] \\
\hline $\begin{array}{l}\text { Nitrazepam, diazepam, } \\
\text { chlordiazepoxide }\end{array}$ & $\begin{array}{l}\text { Methanol-water } \\
(60: 40) \text { containing } \\
0.05 \mathrm{M} \text { ammonium } \\
\text { acetate, } 1.0 \mathrm{ml} / \mathrm{min} .5 \\
\mu \mathrm{m} \text { Spherisob ODS } \\
(250 \times 2.6 \mathrm{~mm})\end{array}$ & $\begin{array}{l}\text { Nitrazepam, } 7 \text { to } \\
1400 \mu \mathrm{g} / \mathrm{ml}\end{array}$ & $\begin{array}{l}\text { Nitrazepam } 3 \\
\mathrm{ng} \text { at }-0.93 \mathrm{~V} \text {. } \\
\text { Diazepam and } \\
\text { chlordiazepox } \\
\text { ide not } \\
\text { detected. } 30 \\
\text { ng for } \\
\text { nitrazepam } \\
\text { and } 300 \mathrm{ng} \\
\text { for both } \\
\text { diazepam and } \\
\text { chlordiazepox } \\
\text { ide at }-1.30 \mathrm{~V} \text {. }\end{array}$ & $\begin{array}{l}\text { Amperometric detector, } 3 \\
\text { mm diameter glassy } \\
\text { carbon electrode in a wall- } \\
\text { jet configuration }\end{array}$ & - & [61] \\
\hline $\begin{array}{l}\text { Chlordiazepoxide and } \\
\text { N-desmethyl- } \\
\text { chlordiazepoxide }\end{array}$ & $\begin{array}{l}\text { Methanol- } \\
\text { isopropanol- } 7.5 \mathrm{mM} \\
\text { acetate buffer pH } 3.5 \\
(53: 5: 42) \text {, at a flow } \\
\text { rate of } 0.9 \mathrm{ml} / \mathrm{min} . \\
300 \times 3.9 \mathrm{~mm} 10 \mu \mathrm{m} \\
\mu \text { Bondapak } \mathrm{C}_{18} \\
\text { column }\end{array}$ & $\begin{array}{l}0.05-2.0 \mu \mathrm{g} / \mathrm{ml} \\
\text { for plasma, } \\
\text { utilising } \\
\text { medazepam as } \\
\text { an internal } \\
\text { standard }\end{array}$ & $5.0 \mathrm{ng}$ & $\begin{array}{l}\text { Differential pulse mode, } \\
-0.820 \mathrm{~V} \text { at a dropping } \\
\text { mercury electrode. }\end{array}$ & $\begin{array}{l}\text { Plasma adjusted to } \\
\mathrm{pH} 9 \text {, extracted } \\
\text { with diethyl ether, } \\
\text { reconstituted in } \\
\text { isopropanol }\end{array}$ & [62] \\
\hline $\begin{array}{l}\text { Insciences Journ } \\
\text { ISSN 1664-171X }\end{array}$ & $\begin{array}{l}\text { Partisil ODS- } 3,110 \mathrm{x} \\
4.7 \mathrm{~mm}, 5 \mu \mathrm{m} \text { column. } \\
0.1 \mathrm{M} \text { ammonium } \\
\text { acetate-acetonitrile } \\
(60: 40 \mathrm{v} / \mathrm{v}) \text { at a flow } \\
\text { rate of } 1.3 \mathrm{ml} / \mathrm{min} .\end{array}$ & $\begin{array}{l}\text { Qualitative. } \\
\text { Ratio between } \\
\text { peak obtained at } \\
+1.1 \mathrm{~V} \text { at and } \\
\text { that obtained at } \\
+1.0 \mathrm{~V} \text { by } \\
\text { parallel dual } \\
\text { electrode } \\
\text { detection. }\end{array}$ & Qualitative & $\begin{array}{l}\text { Parallel dual electrode } \\
\text { detection }(+1.1 \mathrm{~V},+1.0 \mathrm{~V}) \\
\text { as part of diode array, } \\
\text { thermospray mass } \\
\text { spectrometry detection } \\
\text { system. }\end{array}$ & $\begin{array}{l}\text { Quantification } \\
\text { made by diode } \\
\text { array and mass } \\
\text { spectroscopy, of } \\
\text { chlorazepate, } \\
\text { Bromazepam, } \\
\text { Demoxepam, } \\
\text { Nitrazepam, } \\
\text { Clonazepam, } \\
\text { Alprazolam, } \\
\text { Triazolam, } \\
\text { Desalkylflurazepa } \\
\text { m, Nordiazepam, } \\
\text { Temazepam, } \\
\text { Flunitrazepam, } \\
\text { Diazepam, } \\
\text { Midazolam, } \\
\text { Tetrazepam, } \\
\text { Prazepam, }\end{array}$ & [63] \\
\hline
\end{tabular}




\begin{tabular}{|c|c|c|c|c|c|c|}
\hline & & & & & $\begin{array}{l}\text { Halazepam, } \\
\text { Medazepam, } \\
\text { Oxazepam, } \\
\text { Lorazepam and } \\
\text { Chlordiazepoxide. }\end{array}$ & \\
\hline Olanzapine & $\begin{array}{l}150 \times 4.6 \mathrm{~mm}, 5 \mu \mathrm{m} \\
\text { YMC basic column, } \\
\text { mobile phase of } 75 \\
\mathrm{mM} \text { sodium phosphate } \\
(\mathrm{pH} 7) \text {-methanol- } \\
\text { acetonitrile }(48: 26: 26) \text {, } \\
\text { a flow-rate of } 1.2 \\
\mathrm{ml} / \mathrm{min} \text {, and a column } \\
\text { temperature of } 40^{\circ} \mathrm{C} \text {. }\end{array}$ & $\begin{array}{l}0.25-100 \\
\mathrm{ng} / \mathrm{ml}\end{array}$ & $0.25 \mathrm{ng} / \mathrm{ml}$ & $\begin{array}{l}\text { ESA Coulochem model } \\
5100 \text { A electrochemical } \\
\text { detector with a Model } \\
5011 \text { electrode cell. The } \\
\text { electrochemical detector } \\
\text { guard cell was set at }+0.3 \\
\text { V and the analytical cell } 1 \\
+0.2 \mathrm{~V} \text {, cell } 2-0.2 \mathrm{~V} \text {. }\end{array}$ & $\begin{array}{l}\text { Human plasma, } \\
\text { following solid } \\
\text { phase extraction }\end{array}$ & [64] \\
\hline Olanzapine & $\begin{array}{l}250 \times 4.6 \mathrm{~mm}, 5 \mu \mathrm{m}, \\
\text { Ultrasphere Cyano } \\
\text { column, mobile phase } \\
130 \mathrm{mM} \text { ammonium } \\
\text { acetate pH (6.8 not } \\
\text { adjusted), methanol, } \\
\text { acetonitrile (8:6:86) }\end{array}$ & $\begin{array}{l}0.25-50 \mathrm{ng} / \mathrm{ml} \\
\text { (using } 2- \\
\text { methylolanzapin } \\
\text { e as internal } \\
\text { standard). }\end{array}$ & $\begin{array}{l}0.25 \mathrm{ng} / \mathrm{ml} \\
\text { plasma }\end{array}$ & $\begin{array}{l}\text { ESA Coulochem model } \\
5100 \mathrm{~A} \text { electrochemical } \\
\text { detector; guard cell set at } \\
+1.0 \mathrm{~V} \text { (between pump } \\
\text { and injector), the } \\
\text { analytical cell } 1 \text { set at }+0.3 \\
\mathrm{~V} \text {, cell } 2+0.93 \mathrm{~V} \text {. }\end{array}$ & $\begin{array}{l}\text { Human plasma, } \\
\text { following } \\
\text { extraction with } 15 \\
\% \\
\text { dichloromethane } \\
\text { in pentane }\end{array}$ & [65] \\
\hline $\begin{array}{c}\text { Olanzapine and } \\
\text { desmethylolanzapine }\end{array}$ & $\begin{array}{l}\mathrm{C}_{8}, 150 \times 4.6 \mathrm{~mm}, 5 \\
\mu \mathrm{m} \text { using acetonitrile- } \\
\text { phosphate buffer, } 15.4 \\
\mathrm{mM} \mathrm{pH} 3.8, \\
\text { containing } 19.7 \mathrm{mM} \\
\text { triethylamine }(20 / 80) \\
\text { as the mobile phase, } \\
\text { flow-rate } 1.2 \mathrm{ml} / \mathrm{min} \\
\end{array}$ & $\begin{array}{l}5-150 \mathrm{ng} / \mathrm{ml} \text { for } \\
\text { both }\end{array}$ & $\begin{array}{l}1 \mathrm{ng} / \mathrm{ml} \text { for } \\
\text { both }\end{array}$ & $\begin{array}{l}\text { Amperometric detector, } \\
\text { glassy carbon electrode, } \\
+800 \mathrm{mV}\end{array}$ & human plasma & [66] \\
\hline Olanzapine & $\begin{array}{l}\text { YMC basic column } \\
(150 \mathrm{~mm} \text { x } 4.6 \mathrm{~mm}, 5 \\
\mu \mathrm{m}) \text { at a flow-rate of } 1 \\
\mathrm{ml} / \mathrm{min}, 75 \mathrm{mM} \\
\text { phosphate buffer, } \mathrm{pH} \\
\text { 7.0-acetonitrile- } \\
\text { methanol (48:26:26, } \\
\mathrm{v} / \mathrm{v} / \mathrm{v}) \text { mobile phase. }\end{array}$ & $0.25-100 \mathrm{ng} / \mathrm{ml}$ & $0.25 \mathrm{ng} / \mathrm{ml}$ & $\begin{array}{l}\text { ESA Coulochem Model } \\
5200 \text { A electrochemical } \\
\text { detector with a model } \\
5011 \text { electrode cell. } \\
\text { Electrochemical detector } \\
\text { guard cell was set at }-0.3 \\
\text { V and the analytical cell } 1 \\
-0.2 \mathrm{~V} \text {, cell } 2,+0.2 \mathrm{~V} \text {. }\end{array}$ & $\begin{array}{l}\text { human breast } \\
\text { milk, following } \\
\text { solid phase } \\
\text { extraction }\end{array}$ & [67] \\
\hline Olanzapine & $\begin{array}{l}\text { YMC Basic HPLC } \\
\text { column }(5 \mu \mathrm{m}, 150 \mathrm{x} \\
4.6 \mathrm{~mm}, 75 \mathrm{mM} \mathrm{pH} \\
7.0 \text { phosphate buffer- } \\
\text { methanol-acetonitrile } \\
(48: 26: 26, \mathrm{v} / \mathrm{v} / \mathrm{v}), 1.2 \\
\mathrm{ml} / \mathrm{min}\end{array}$ & $0.5-100 \mathrm{ng} / \mathrm{ml}$ & $0.5 \mathrm{ng} / \mathrm{ml}$ & $\begin{array}{l}\text { ESA Coulochem Model } \\
5100 \text { A electrochemical } \\
\text { detector with a model } \\
5011 \text { with a dual analytical } \\
\text { cell. Cell } 1-0.2 \mathrm{~V} \text {, cell } 2 \\
+0.2 \mathrm{~V}, \text { Model } 5010 \text { guard } \\
\text { cell, }-0.3 \mathrm{~V} \text {. }\end{array}$ & $\begin{array}{l}\text { rat brain tissue, } \\
\text { after liquid } \\
\text { extraction with } \\
15 \% \\
\text { dichloromethane } \\
\text { in cyclohexane }\end{array}$ & [68] \\
\hline $\begin{array}{l}\text { Nitrazepam and } \\
\text { clonazepam }\end{array}$ & $\begin{array}{l}\text { LiChrosorb RP-18 } 250 \\
\text { x } 4.0 \mathrm{~mm} 5 \mu \mathrm{m} .0 .1 \mathrm{M} \\
\text { potassium nitrate- } 0.02 \\
\mathrm{M} \text { sulphuric } \\
\text { acid/methanol }(50 / 50 \\
\% \mathrm{v} / \mathrm{v} 1.0) 1.0 \mathrm{ml} / \mathrm{min}\end{array}$ & - & - & $\begin{array}{l}\text { Static mercury drop } \\
\text { electrode- } 0.85 \mathrm{~V}\end{array}$ & - & [69] \\
\hline Nitrazepam & $\begin{array}{l}\text { ODS hypersil }(5 \mu \mathrm{m} \\
100 \mathrm{~mm} \times 4.6 \mathrm{~mm}) . \\
1.0 \mathrm{ml} / \mathrm{min} \text { water- } \\
\text { methanol, } 50 / 50 \% \mathrm{v} / \mathrm{v} \\
0.1 \mathrm{M} \mathrm{KNO}_{3}, 10^{-3} \mathrm{M} \\
\mathrm{HNO}_{3}\end{array}$ & $10^{-4}-4 \times 10^{-8} \mathrm{M}$ & $0.7 \mathrm{pM}$ & $\begin{array}{l}\text { Dropping mercury } \\
\text { electrode }\end{array}$ & $\begin{array}{l}\text { bromazepam and } \\
\text { diazepam also } \\
\text { shown }\end{array}$ & [70] \\
\hline Clotiazepam & $\begin{array}{l}\text { Bondpak } \mathrm{C}_{18} 300 \times 3.9 \\
\text { mm. Methanol-water } \\
\text { ( } 70: 30) \text { containing } \\
0.01 \mathrm{M} \text { acetate buffer } \\
\text { pH } 4 \text {. Flunitrazepam } \\
\text { as internal standard. }\end{array}$ & - & $\begin{array}{l}2.5 \mu \mathrm{g} \text { on } \\
\text { column }\end{array}$ & $\begin{array}{l}\text { Glassy carbon electrode, } \\
\text { amperometric }\end{array}$ & Tablets & [71] \\
\hline $\begin{array}{l}\text { Olanzapine, } N- \\
\text { desmethyl and 2- } \\
\text { hydroxymethyl } \\
\text { metabolites }\end{array}$ & $\begin{array}{l}75 \mathrm{mM} \text { phosphate } \\
\text { buffer, adjusted to } \mathrm{pH} \\
7 \text { with } 5 \mathrm{mM} \mathrm{NaOH} \text {, } \\
\text { acetonitrile and } \\
\text { methanol }(48 / 26 / 26 \\
\mathrm{v} / \mathrm{v} / \mathrm{v}) . \text { YMC basic } \\
\text { column, } 150 \times 4.6 \\
\mathrm{~mm}, 5 \mu \mathrm{m} .\end{array}$ & $\begin{array}{l}\text { 1-100 ng/ml, } \\
\text { using } \\
\text { LY170222 (2- } \\
\text { methylolanzapin } \\
\text { e) as internal } \\
\text { standard }\end{array}$ & $\begin{array}{l}1 \mathrm{ng} / \mathrm{ml} \text { after } \\
\text { solid-phase } \\
\text { extraction } \\
\text { (Bond Elute } \\
\text { LRC } \\
\text { cartridges) }\end{array}$ & $\begin{array}{l}\text { ESA Coulochem II (Model } \\
5200 \text { ) electrochemical } \\
\text { detector with a model } \\
5010 \text { dual analytical } \\
\text { detector. Cell } 1-0.2 \mathrm{~V} \text {, cell } \\
2+0.2 \mathrm{~V} \text {, Model } 5010 \\
\text { guard cell, }-0.3 \mathrm{~V} \text {. }\end{array}$ & Rat plasma & [72] \\
\hline $\begin{array}{c}\text { Clozapine, } N \text { - } \\
\text { desmethylclozapine, }\end{array}$ & $\begin{array}{l}\text { ODS- } 3 \text { column, } \\
\text { methanol and } 0.1 \mathrm{M}\end{array}$ & - & - & $\begin{array}{l}+0.6,+0.6 \text { and }+0.35 \mathrm{~V} \text { at } \\
\mathrm{pH} 4.56 \text { and }+0.48,+0.48\end{array}$ & - & [73] \\
\hline
\end{tabular}




\begin{tabular}{|c|c|c|c|c|c|c|}
\hline $\begin{array}{l}\text { olanzapine and } \\
\text { olanzapine }\end{array}$ & $\begin{array}{l}\text { phosphate } \mathrm{pH} 4.56 \text { or } \\
\text { pH } 5.56 \text { buffer }(60: 40 \\
\mathrm{v} / \mathrm{v})\end{array}$ & & & $\begin{array}{l}\text { and }+0.3 \mathrm{~V} \text { at } \mathrm{pH} 5.56 \text { for } \\
\text { clozapine, } N \text { - } \\
\text { desmethylclozapine, } \\
\text { olanzapine and olanzapine } \\
\text { respectively }\end{array}$ & & \\
\hline Olanzapine & $\begin{array}{l}\text { Varian ResElut } \mathrm{C}_{8} 150 \\
\text { x } 4.6 \mathrm{~mm}, 5 \mu \mathrm{m}, \\
\text { acetonitrile- } \\
\text { phosphate buffer } \mathrm{pH} \\
2.5\end{array}$ & $2-100 \mathrm{ng} / \mathrm{ml}$ & $\begin{array}{l}1.4 \mathrm{ng} / \mathrm{ml} \text {, } \\
\text { solid-phase } \\
\text { extraction } \mathrm{C}_{8} \\
\text { Bond elute }\end{array}$ & $\begin{array}{l}\text { Glassy carbon electrode } \\
+0.900 \mathrm{~V}\end{array}$ & Human plasma & [74] \\
\hline Olanzapine & $\begin{array}{l}\text { YMC basic column, } \\
150 \times 4.6 \mathrm{~mm}, 5 \mu \mathrm{m} . \\
75 \mathrm{mM} \text { phosphate } \\
\text { buffer/methanol/aceto } \\
\text { nitrile } 48 / 26 / 26(\mathrm{v} / \mathrm{v} / \mathrm{v})\end{array}$ & $\begin{array}{l}0.250-100 \\
\mathrm{ng} / \mathrm{ml} \text {, using } \\
\text { LY170222 (2- } \\
\text { methylolanzapin } \\
\text { e) as internal } \\
\text { standard }\end{array}$ & $\begin{array}{l}0.25 \mathrm{ng} / \mathrm{ml} \\
\text { limit of } \\
\text { quantitation } \\
\text { following } \\
\text { automated } \\
\text { solid phase } \\
\text { extraction } \\
\text { with Bond } \\
\text { Elute Certify } \\
\text { cartridges in a } \\
96 \text {-well plate } \\
\text { formate }\end{array}$ & $\begin{array}{l}\text { Glassy carbon electrode, } \\
\text { amperometric, potential } \\
\text { not stated. }\end{array}$ & Human plasma & [75] \\
\hline Olanzapine & $\begin{array}{l}\mathrm{C}_{8} \text { reversed phase } \\
\text { column }(150 \mathrm{~mm} \times 4.6 \\
\mathrm{mm}, 5 \mu \mathrm{m}) \text {, using a } \\
\text { mobile phase } \\
\text { composed of methanol } \\
\text { and a phosphate buffer } \\
(44.0 \mathrm{mM} \text {, pH } 3.5) \text {, } \\
\text { containing } \\
\text { triethylamine ( } 21: 79 \text {, } \\
\mathrm{v} / \mathrm{v}) \text {, flowing at } 1.2 \\
\mathrm{ml} / \mathrm{min}\end{array}$ & $\begin{array}{l}0.2-100.0 \mathrm{ng} / \mathrm{ml} \text {, } \\
\text { using } \\
\text { LY170222 (2- } \\
\text { methylolanzapin } \\
\text { e) as internal } \\
\text { standard }\end{array}$ & $\begin{array}{l}0.20 \mathrm{ng} / \mathrm{ml} \\
\text { limit of } \\
\text { quantitation, } \\
\text { solid-phase } \\
\text { extraction } \\
\text { Waters Oasis } \\
\text { hydrophilic- } \\
\text { lipophilic } \\
\text { balance } \\
\text { cartridges. }\end{array}$ & $\begin{array}{l}\text { ESA Coulochem III } \\
\text { (Model 5011) } \\
\text { electrochemical detector } \\
\text { with a dual analytical } \\
\text { detector. Cell } 1+0.350 \mathrm{~V} \text {, } \\
\text { cell } 2-0.200 \mathrm{~V} \text {. }\end{array}$ & Rat brain & [76] \\
\hline
\end{tabular}

Table 1. Pre-2006 applications of liquid chromatography coupled with electrochemical detection for the determination of benzodiazepines

These redox processes have been shown to occur with a variety of electrode materials and as a result a range of different electrochemical techniques, including polarography and voltammetry have been successfully utilised. These have been shown to be sensitive, economic and flexible and have been exploited for the determination of a range of parent benzodiazepines and their metabolites in complicated matrices such as blood [28-30], and forensic samples [31-34]. Utilising techniques such as adsorptive stripping voltammetry [35] detection limits in the $\mathrm{nM}$ to $\mu \mathrm{M}$ range are readily obtainable. Some recent reports describe the application of ion selective electrodes [36-39] and electrochemical biosensors $[40,41]$ for the determination of benzodiazepines. Electrochemical detection can be readily employed with flow injection analysis and liquid chromatography employing both single and dual electrode detection systems. Recent studies have illustrated the possibility of using electrochemistry to simulate drug metabolism and has been coupled to mass spectroscopy for product identification.

This review focuses on liquid chromatography coupled with electrochemically based techniques for the determination of the benzodiazepine class of drugs. Liquid chromatographic approaches using both single and dual electrode detection are included as well as electrochemical derivatisation in conjugation with mass spectroscopy. Details of methodology, design and performance of selected 
applications are given and discussed for research papers published in the past seven years with reports made prior to 2006 being summarised in table 1. A number of earlier investigations have already been reviewed [28, 42-46]

\section{Liquid Chromatography Electrochemical Detection of Benzodiazepines}

Many benzodiazepines are known to be thermal unstable and form common degradation products. As a result techniques such as liquid chromatography which can be undertaken at ambient or near ambient temperatures are popular methods for the separation and quantification of these drugs $[21,47,48]$. Recently, Trojanowicza has reviewed the utilisation of electrochemical detection with both flow injection analysis [49] and liquid chromatography [47] for a range of compounds. The underlying theory and applications including the determination of several benzodiazepines was described [43,50-52]. Attention first focused on LC-ED with regard to neurochemical problems, leading to the first commercially available detectors being produced in 1974 [52]. These systems had several advantages including enhanced selectivity, low detection limits and low cost.

Normal phase chromatography cannot generally be utilised as nonpolar solvents are not suitable for use with common buffers. However, recent studies have shown the possibility of utilising related techniques such as hydrophilic interaction liquid chromatography with electrochemical detection [53].

\section{Applications}

Table 1 gives a summary of the liquid chromatographic approaches that have been reported prior to 2006. A variety of different approaches has been described including coulometric and amperometric and dual electrode systems. Both $\mathrm{Hg}$ and carbon based working electrodes have been employed successfully for benzodiazepine determination in complex samples such as blood, milk and tissue. More recently, Martins et al [54] have reported on the determination of diazepam, clonazepam, flunitrazepam and nitrazepam using boron doped diamond electrode (BDDE), as part of a liquid chromatographic system. Cyclic voltammetry was employed to investigate the electrochemical behaviour of the four benzodiazepines at the BDDE in 0.1 M phosphate buffer at $\mathrm{pH} 3.5,6.0$ and 8.0 with the optimum response obtained at $\mathrm{pH}$ 3.5. Chromatographic separation was achieved using an octyldecyl stationary phase in conjugation with a mobile phase comprising sodium phosphate ( $\mathrm{pH} 3.5$; $0.10 \mathrm{M})$ acetonitrile $(65: 35, \mathrm{v} / \mathrm{v})$, at a flow rate of $1.2 \mathrm{ml} / \mathrm{min}$. A thin layer amperometric detector operated in the pulse mode was used for the detection of the benzodiazepines. The optimum wave form for the reduction was reported to be $-1.9 \mathrm{~V},+1.5 \mathrm{~V}$ and $-0.5 \mathrm{~V}$, with repetition time of $0.5 \mathrm{~s}$. Detection limits of $0.5,0.6$ and $2.0 \mu \mathrm{g} / \mathrm{ml}$ were reported for nitrazepam, clonazepam and diazepam respectively. Analysis of pharmaceutical tablet formulations showed good agreement with that found by liquid chromatography with UV diode array detection.

Liquid chromatography dual electrode detection (LC-DED) has been shown to be a powerful analytical technique and has been utilised for the determination of a number of benzodiazepines (table 1). Recently, LC-DED in the redox mode has recently been explored by Honeychurch et al [55] for the determination of nitrazepam in serum. In this approach, two electrochemical cells are arranged in series after the analytical chromatographic column. The first upstream cell is used as the "generator" cell to reduce nitrazepam to the corresponding hydroxylamine species, which is then detected at the 
second downstream "detector" cell via oxidation to the corresponding nitroso species. The advantage of this approach is that the electrochemically generated product is much more readily oxidized or reduced than the parent compound; consequently lower applied potentials are required for its determination, so allowing for improvements in selectivity of the system, as the detector potential is operated at a lower applied potential. The sensitivity of the system is also improved as a result of the lower background currents occurring at the detector electrode compared with those obtained at the high potentials required for direct electrochemical detection. This can be readily seen in figure 2 , where chromatograms obtained for fixed $300 \mathrm{ng}$ injections of nitrazepam using the reductive mode and DED mode detection techniques are shown. As can be readily seen, the best signal-to-noise ratio was obtained by using the redox mode (figure $2 b$ and $2 c$ ). Incidentally, it was found impossible to operate the detector at low nA ranges in the direct reductive mode, (figure $2 \mathrm{a}$ ) due to excessive baseline drift; this probably arises from the ingress of oxygen into the mobile phase even though degassing was performed continuously. In addition, an unresolved pre-peak was seen in the reductive mode (figure 2a); this would result in significant errors when calculating nitrazepam levels in serum samples. Such effects demonstrate the superior analytical responses that can be obtained using DED. Using LCDED, nitrazepam levels in both human and bovine serum could be successfully determined following a simple, rapid sample preparation step. A mean recovery of $74 \%(\% \mathrm{CV}=7.8 \%)$ was obtained for a human serum sample fortified with $1670 \mathrm{ng} / \mathrm{ml}$ nitrazepam.

More recently, a variation on this technique for the determination of both nitrazepam, and flunitrazepam, in beverage samples such as Pepsi Max ${ }^{\circledR}$ has been reported by Honeychurch and Hart [56]. In this approach a carbon fibre veil electrode (CFVE) was incorporated as the generator electrode to increase the conversion efficiency of this flow cell. Cyclic voltammetric studies were performed to ascertain the redox behaviour of nitrazepam and flunitrazepam at a CFVE in the optimised mobile phase. As can be seen in figure 3, cyclic voltammetric behaviour of the two compounds was similar to that obtained with a GCE.

Interestingly, a novel reduction-reduction LC-DED approach could be exploited to measure these two nitro containing drugs. The initial reduction reaction occurring at the at the generator electrode was postulated to result from a two $2 \mathrm{e}, 2 \mathrm{H}^{+}$reduction of the 7-nitro group first to the corresponding nitroso species, with the associated loss of water. This was then followed by a further $2 \mathrm{e}^{-}, 2 \mathrm{H}^{+}$ reduction at the detector electrode to the corresponding hydroxylamine. A linear range of 2.0 to 100 $\mu \mathrm{g} / \mathrm{ml}$, with a detection limit of $20 \mathrm{ng} / \mathrm{ml}$ was obtained. Only a simple sample extraction procedure was required prior to analysis using the optimised LC-DED procedure. A mean recovery of $95.5 \%$ $(\% \mathrm{CV}=4.5 \%)$ for nitrazepam and $78.0 \%(\% \mathrm{CV}=8.8 \%)$ was achieved for a beverage sample spiked at $1.0 \mu \mathrm{g} / \mathrm{ml}$ nitrazepam and $1.47 \mu \mathrm{g} / \mathrm{ml}$ flunitrazepam. 
Figure 2. Chromatograms obtained for $300 \mathrm{ng}$ of nitrazepam in (a) reductive mode and (b) and (c) redox mode. Detector currents ranges: $10 \mathrm{nA} \mathrm{FSD} \mathrm{for} \mathrm{(a)} \mathrm{and} \mathrm{(b);} 2$ nA FSD for (c). Reprinted with permission from Honeychurch K.C., Smith G.C., Hart J.P., Voltammetric Behavior of Nitrazepam and

Its Determination in Serum Using Liquid Chromatography with Redox Mode Dual-Electrode

Detection, Anal. Chem. 2006, 78, 416-423. Copyright 2006 American Chemical Society.
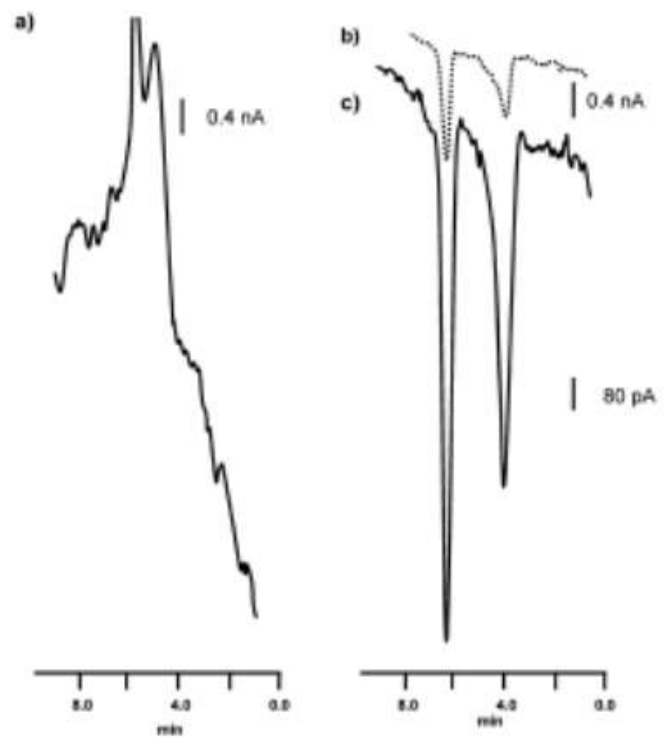

Saracino et al [57] have reported the application of high-performance liquid chromatography with both coulometric and diode array detection for the therapeutic drug monitoring of patients with bipolar disorders; the patients were treated with olanzapine and lamotrigine. Chromatographic separation was achieved with a reversed-phase $\mathrm{C}_{8}$ column $(150 \mathrm{x} 4.6 \mathrm{~mm}, 5 \mu \mathrm{m})$ using a mobile phase composed of methanol (27\%) and a $50.0 \mathrm{mM}$, pH 3.5 phosphate buffer $(73 \%)$. For the analysis of olanzapine and its main metabolite, N-desmethylolanzapine, a dual coulometric detector was used, with the first downstream electrode 1 set at $-200 \mathrm{mV}$ and the subsequent upstream electrode 2 at $+500 \mathrm{mV}$. Lamotrigine was determined using diode array detection at $220 \mathrm{~nm}$ with the two detectors connected in series. For the analysis of biological samples, a clean-up procedure was implemented by means of solid-phase extraction using phenyl cartridges and eluting the analytes with methanol. Recoveries greater than $90 \%$, with an associated precisions of $<3.4 \%$ were reported. Linear responses were obtained between 0.1 and $50.0 \mathrm{ng} / \mathrm{ml}$ for olanzapine, 0.1 and $25.0 \mathrm{ng} / \mathrm{ml}$ for N-desmethylolanzapine, and between 0.25 and $10.0 \mu \mathrm{g} / \mathrm{ml}$ for lamotrigine. The method was applied successfully to some human plasma samples drawn from bipolar patients undergoing combined therapy with the two drugs. 
Figure 3. Cyclic voltammograms, for: (a) carbon fibre veil electrode (CFVE) 0.1 mM nitrazepam, (b) CFVE $0.1 \mathrm{mM}$ flunitrazepam (c) GCE $1.0 \mathrm{mM}$ nitrazepam and (d) GCE $1.0 \mathrm{mM}$ flunitrazepam. i denotes the absence of and ii the presence of the benzodiazepine. Starting potential $0.0 \mathrm{~V}$, initial switching potential $-1.5 \mathrm{~V}$, second switching potential $+0.6 \mathrm{~V}$ at a scan rate of $100 \mathrm{mVs}{ }^{1}$, in $45 \%$ acetonitrile-55\% acetate buffer (50 mM, pH 4.1) J. Solid State Electr. 12, 2008 1317-1324, Determination of Flunitrazepam and Nitrazepam in Beverage Samples by Liquid Chromatography with Dual Electrode Detection Using a Carbon Fibre Veil Electrode, Honeychurch K.C., Hart J.P., with kind permission from Springer Science+Business Media B.V.
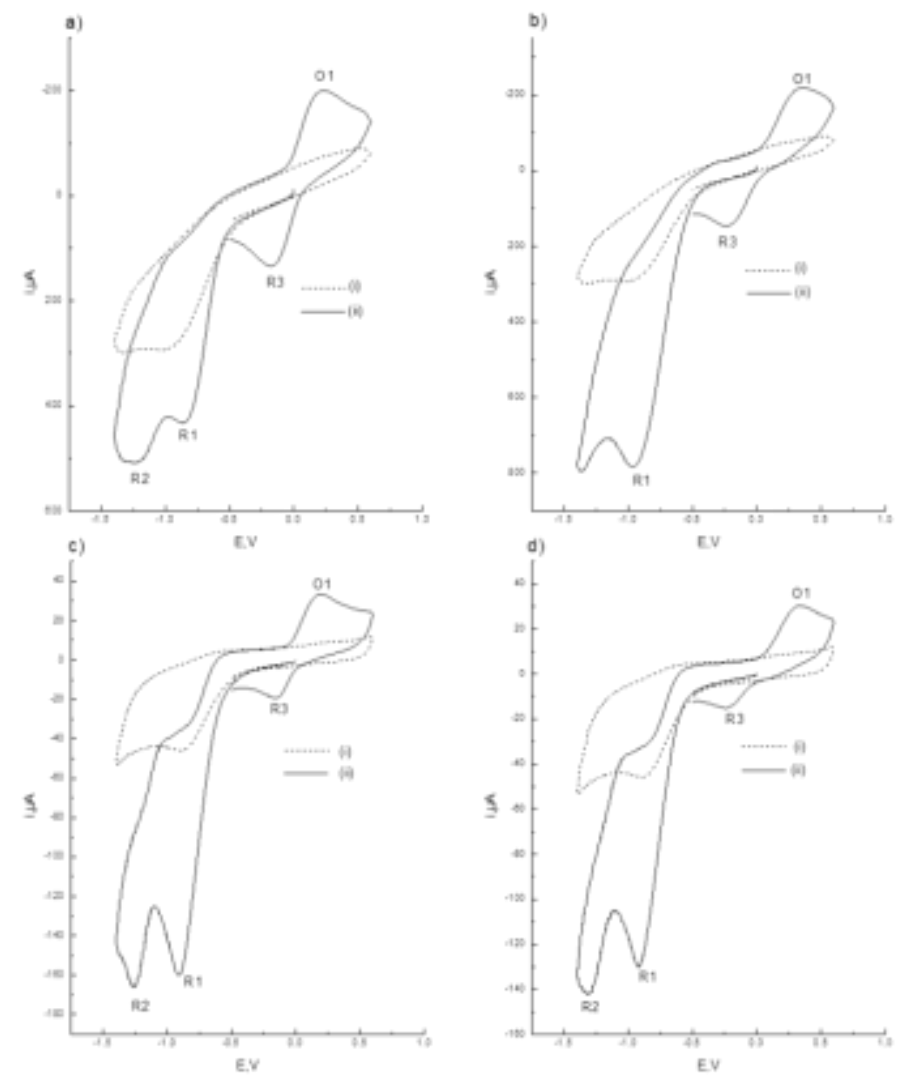

In an alternative approach, Kobylińska et al [58] successfully utilised HPLC with amperometric detection at $+0.6 \mathrm{~V}$ for the determination of olanzapine in human plasma with a glassy carbon working electrode, cleaned by pulsing the applied potential. Blood was collected from volunteers and centrifuged at $3500 \mathrm{rpm}$ the separated plasma was decanted and ascorbic acid was added to protect the olanzapine from oxidation. The internal standard, clozapine was then added to $0.5 \mathrm{ml}$ of the resulting plasma sample and after the addition of $0.25 \mathrm{ml}$ of $40 \mathrm{mM}$ sodium carbonate, extracted with $2 \mathrm{ml}$ of ethyl acetate, by shaking for 5 minutes. The two phases were separated by holding the sample/solvent mixture at $-70{ }^{\circ} \mathrm{C}$ for 10 minutes. The resulting organic phase was then evaporated to dryness and reconstituted in a mixture of $200 \mu \mathrm{l}$ of methanol and $200 \mu \mathrm{l}$ of $0.06 \mathrm{M}$ ammonium acetate. This was 
then mixed and introduced to the HPLC system. Separations were achieved using a $125 \mathrm{x} 4.0 \mathrm{~mm}, 5$ $\mu \mathrm{m}_{18}$ column with a mobile phase of $0.06 \mathrm{M}$ ammonium acetate buffer, $\mathrm{pH} 5.9$, acetonitrile and methanol at flow rate of $0.69 \mathrm{ml} / \mathrm{min}$. The method was able to determine olanzapine plasma concentrations after the administration of one $10 \mathrm{mg}$ oral dose over a period of 120 hours. A linear response over the range $0.313-25.00 \mathrm{ng} / \mathrm{ml}$ was reported, the former being the limit of quantification.

Recently, Honeychurch et al [59] successfully exploited a previously unreported electrochemical redox reaction for flunitrazepam, lorazepam and diazepam for their determination in serum by LCDED. The initial cyclic voltammetric investigation represented the first report on the anodic behaviour of diazepam and lorazepam. Previous reports had only recorded the reduction of the 4,5-azomethine group, with no further redox peaks reported. However, in this study, new oxidation peaks were recorded which did not occur without prior reduction of the molecule. These redox processes were investigated for the possible LC-DED determination. Studies were performed to optimise the chromatographic conditions and were found to be $50 \%$ acetone, $50 \% 100 \mathrm{mM} \mathrm{pH} 2$ phosphate buffer at a flow rate of $0.8 \mathrm{ml} / \mathrm{min}$, employing a Hypersil $\mathrm{C}_{18}, 5 \mu \mathrm{m}, 250 \mathrm{~mm}$ x $4.6 \mathrm{~mm}$ column held at $40{ }^{\circ} \mathrm{C}$ using a generator potential of $-2.4 \mathrm{~V}$ ( $v s$. stainless steel) and detector potential of $+1.0 \mathrm{~V}$ ( $v s$. $\mathrm{Ag} / \mathrm{AgCl}$ ). Enhancement in both peak height and peak area (coulombs) was seen with decreasing flow rate, probably resulting from improvements in the electrolytic conversion efficiency of the cell at lower flow rates. This decrease in flow rate results in a higher conversion of the analyte at the working electrode and consequently, larger peak areas (coulombs) are expected. Figure 4 shows the resulting chromatograms obtained under the optimised conditions for fortified and unfortified bovine serum.

Figure 4. Typical chromatogram obtained in the redox mode for bovine serum extracts. Solid line, fortified with lorazepam $(16.0 \mathrm{mg} / \mathrm{l})$, flunitrazepam $(1.60 \mathrm{mg} / \mathrm{l})$ and diazepam $(14.2 \mathrm{mg} / \mathrm{l})$, dotted line unadulterated. Reproduced from Ref. [59] with permission from The Royal Society of Chemistry.

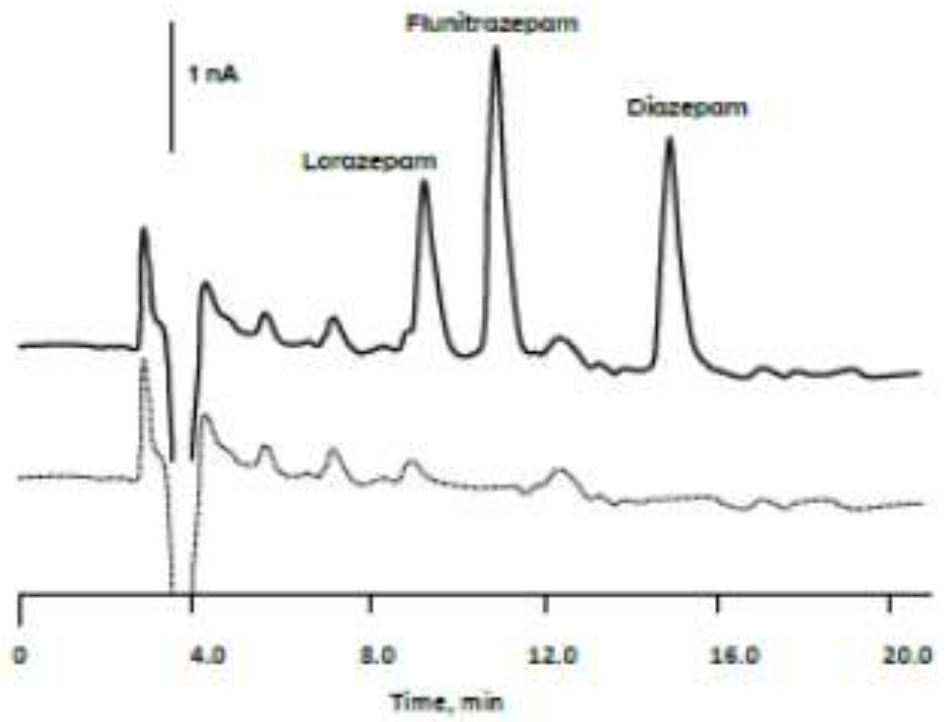


Figure 5. Comparison of the oxidative metabolites of tetrazepam found in urine (6 h after Myolastan intake), in an incubation mixture with rat liver microsomes (RLMs) and in an electrochemical simulation (EC). Peak assignment: 1, tetrazepam- $\mathrm{CH}_{3}+\mathrm{O} ; 2,3,6-8,10$, tetrazepam $+\mathrm{O} ; 4$, tetrazepam- $\mathrm{H}_{2}+\mathrm{O} ; 5$, tetrazepam- $2 \mathrm{H}_{2}+\mathrm{O} ; 9$, tetrazepam- $2 \mathrm{H}_{2} ; 11$, tetrazepam- $\mathrm{CH}_{3} ; 12$, tetrazepam- $\mathrm{H}_{2}$; *Peaks which were also present in a Myolastan solution without electrochemical oxidation. Reprinted from Journal of Chromatography A, 1216, 15, Baumann A., Lohmann W., Schubert B., Oberacher H.,

Karst U., Metabolic studies of tetrazepam based on electrochemical simulation in comparison to in vivo and in vitro methods, 3192-3198, Copyright (2009), with permission from Elsevier.
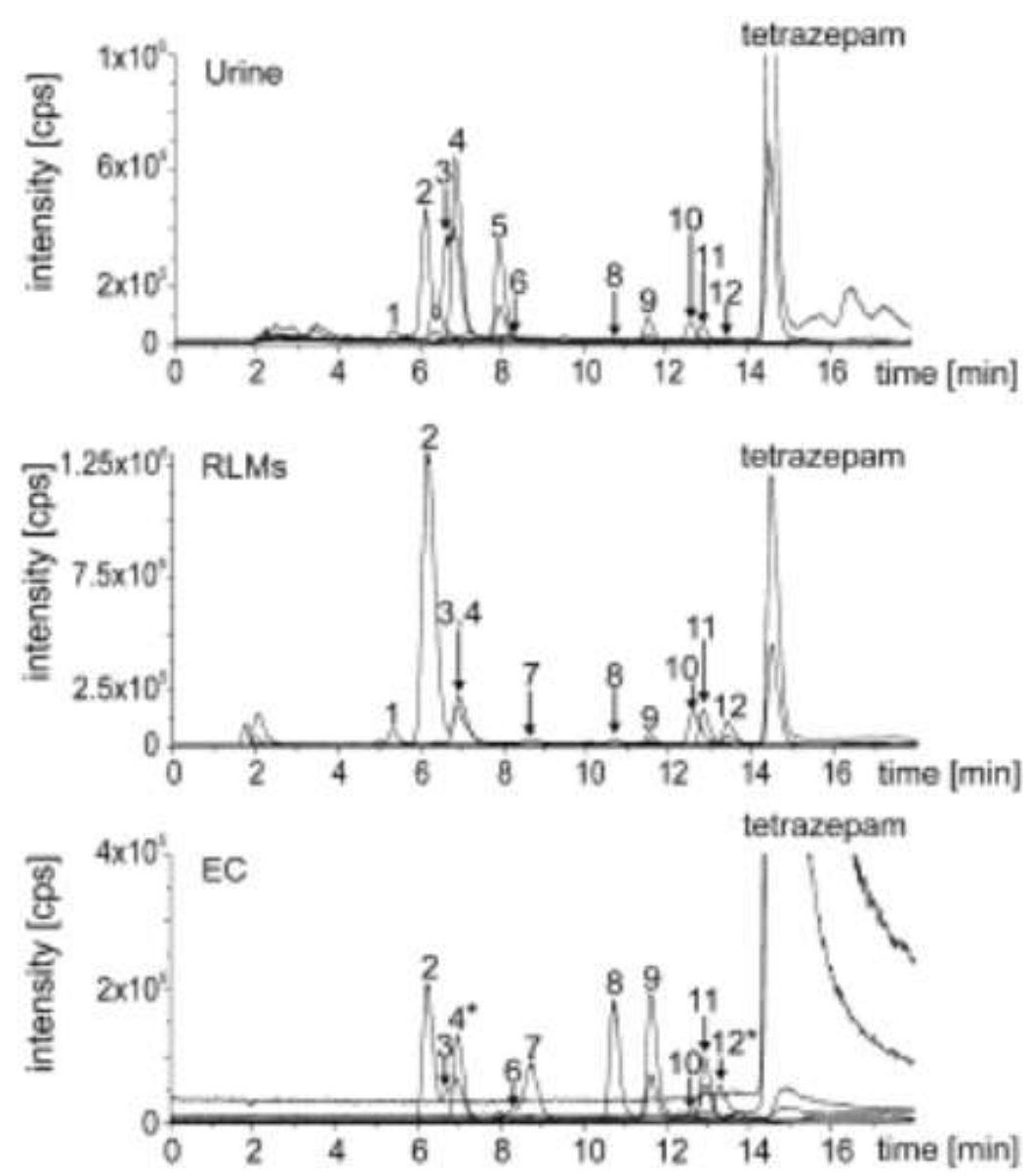

\section{Combined On-line Electrochemistry/ Mass Spectrometry Analysis}

Recently reports have shown the possibility of utilising on-line electrochemistry/mass spectrometry (EC/MS) as a rapid economic method for early-stage drug metabolite discovery and to anticipate biological oxidation patterns. Baumann et al [77] have utilised LC-MS in series with an electrochemical wall-jet generator electrode to model the metabolic pathway of tetrazepam. The electrochemical results were compared to results from microsomal incubations, and to those generated 
by in vivo studies obtained with urine samples from a patient after tetrazepam delivery (Figure 5). The tetrazepam sample was injected into the electrochemical wall-jet cell by syringe pump; the applied potential was $+2.0 \mathrm{~V}$. The resulting electrochemically generated oxidation products were then separated and determined by LC-MS. A number of metabolites were identified, including nortetrazepam and 3-hydroxytetrazepam and notably diazepam. Earlier studies by Mouithys-Mickalad et al [78] and van Leeuwen [27] utilised a similar approach to study the metabolism of clozapine. These authors employed different applied potentials to a porous carbon electrode, and were able to generate a variety of hydroxylated and demethylated species. Hydroxylated species were reported to be most abundant using a potential of $+0.4 \mathrm{~V}$, with demethylated species being produced at $+0.7 \mathrm{~V}$ ( $v s$. $\mathrm{Pd} / \mathrm{H}_{2}$ ). The addition of reduced glutathione was found to result in the formation of a number of isomeric glutathione adducts, reportedly similar to that described in the literature for phase I and II metabolism.

\section{Conclusion}

The benzodiazepines class of drugs have a long history of pharmaceutical usage and are still commonly used medically for a number of conditions. However, reports have described their use in criminal activity and their contamination of the environment has now become now a more commonly reported problem. The realisation that benzodiazepines are characterised by a facile electrochemically reducible azomethine group, with a number also containing other electro-active groups, such as, nitro, hydroxyl and N-oxide has resulted in their determination using electrochemical detection methods following HPLC with a range of different electrode materials.

Applications for the liquid chromatographic electrochemical determination of 1,4-benzodiazepines have utilised both reductive and more recently dual electrode modes of detection. Both approaches allow for low detection limits, and have been shown to be applicable for the determination complicated samples, such as serum and forensic samples. However, the reductive mode has been shown to suffer from common interferences, such as oxygen.

New analytical developments will continue to be made for other areas other than medical and pharmaceutical analysis, such as in forensic and environmental analysis and has already been shown for the simulation of drug metabolism. The development of new benzodiazepines and related drugs, such as zaleplon and zolpidem will also drive the further developments of electrochemical assays for this important class of drugs.

\section{Acknowledgements}

We are grateful to the University of West of England for their support and would like to thank all the researchers whose work has been described in this review.

\section{References}

[1] Sternbach L.H., 1,4-benzodiazepine 4-oxides, 1959, United States Patent Office, 2, 893, 992. 
[2] Tan K.R., Rudolph U., Lüscher C., Hooked on benzodiazepines: GABAA receptor subtypes and addiction, Trends Neurosci. 2011, 34, 188-197.

[3] Licata S.C., Rowlett J.K., Abuse and dependence liability of benzodiazepines-type drugs: GABAA receptor modulation and beyond, Pharmacol. Biochem. Behav. 2008, 90, 74-89.

[4] Riss J., Cloyd J., Gates J., Collins S., Benzodiazepines in epilepsy: pharmacology and pharmacokinetics, Acta Neurol. Scand. 2008, 118, 69-86.

[5] Kahn C.M., Line S., Aiello S.E., ed. 2005, The Merck Veterinary Manual (9th Ed.), Wiley.

[6] Sternbach L.H., The Benzodiazepine Story, J. Med. Chem. 1979, 22, 1-7.

[7] Donoghue J., Lader M., Usage of benzodiazepines: A review, Int. J. Psychiatry Clin. Pract. 2010, $14,78-87$.

[8] Lader M.H., Limitations on the use of benzodiazepines in anxiety and insomnia: are they justified? Eur. Neuropsychopharmacol. 1999, 9 Suppl. 6, S399-S405.

[9] Westbury J., Jackson S., Gee P., Peterson G., An Effective Approach to Disease Antipsychotic and Benzodiazepine Use in Nursing Homes: The RedUSe Project, Int. Psychogeriatr. 2010, 22, 26-36.

[10] Madhusodanan S., Bogunovic O., Safety of Benzodiazepines in the Geriatric Population, Expert Opinion Patient Safety, 2004, 3, 485-493.

[11] Djezzar S., Questel F., Burin E., Dally S., Chemical submission: results of 4-year French inquiry, Int. J. Legal Med. 2009, 123, 213-219.

[12] Scott-Ham M., Burton F.C., Toxicological findings in cases of alleged drug-facilitated sexual assault in the United Kingdom over a 3-year period, J. Clin. Forensic Med. 2005, 12, 175-186.

[13] Madea B., Mußhoff F., Knock-Out Drugs: Their Prevalence, Modes of Action, and Means of Detection, Dtsch. Arztebl. Int. 2009, 106, 341-347.

[14] Calisto V., Esteves V.I., Psychiatric Pharmaceuticals in the Environment, Chemosphere, 2009, 77, 1257-1274.

[15] Collier A.C., Pharmaceutical Contaminants in Potable Water: Potential Concerns for Pregnant Women and Children, EcoHealth, 2007, 4, 164-171.

[16] Pascoe D., Karntanut W., Müller C.T., Do Pharmaceuticals Affect Freshwater Invertebrates? A Study with the Cnidarian Hydra vulgaris, Chemosphere, 2003, 51, 521-528.

[17] Salamone S.J. (ed.) Benzodiazepine and GHB, Detection and Pharmacology; Humana Press.: New Jersey, 2002.

[18] Bertol E., Vaiano F., Furlanetto S., Mari F., Cross-reactivities and structure-reactivity relationships of six benzodiazepines to EMIT(®) immunoassay, J. Pharm. Biomed. Anal. 2013, 84, 168-172.

[19] Bertol E., Vaiano F., Borsotti M., Quercioli M., Mari F., Comparison of Immunoassay Screening Tests and LC-MS-MS for Urine Detection of Benzodiazepines and Their Metabolites: Results of a National Proficiency Test, J. Anal. Toxicol. 2013, 37, 659-664.

[20] Thevis M., Krug O., Geyer H., Wenzel F., Bux J., Stahl L., Hollmann W., Thom A., Schänzer W., Monitoring drug residues in donor blood/plasma samples using LC-(MS)/MS--a pilot study. Drug Test. Anal. 2013, 5,380-383.

[21] Samanidou V.F., Uddin M.N., Papadoyannis I.N., Benzodiazepines: sample preparation and HPLC methods for their determination in biological samples, Bioanalysis, 2009, 1, 755-784. 
[22] Doctor E.L., McCord B., Comparison of aggregating agents for the surface-enhanced Raman analysis of benzodiazepines, Analyst, 2013, 138, 5926-5932.

[23] Maupas B., Fleury M.B., Incidence of the dehydration step on the electrochemical behaviour of 3hydroxy 2-one benzodiazepine compounds (oxazepam and lorazepam) in aqueous acid media at the mercury electrode, Electrochim. Acta, 1982, 27, 141-147.

[24] Oelschläger H. Polarographic analysis of psychotropic drugs, Bioelectroch. Bioener. 1983, 10, 25 36.

[25] Butkiewicz K., Polarographic study of some derivatives of 3H-1,5-benzodiazepine, J. Electroanal. Chem., 1978, 90, 271-281.

[26] Farhadi K., Karimpour A., Electrochemical behavior and determination of clozapine on a glassy carbon electrode modified by electrochemical oxidation, Anal. Sci. 2007, 23, 479-483.

[27] van Leeuwen S.M., Blankert B., Kauffmann J.M. Karst U., Prediction of clozapine metabolism by on-line electrochemistry/liquid chromatography/mass spectrometry, Anal. Bioanal. Chem. 2005, $382,742-750$.

[28] Smyth W.F., Voltammetric Determination of Molecules of Biological Significance; Wiley.: Chichester, 1992.

[29] El-Maali N.A., Voltammetric analysis of drugs, Bioelectrochemistry 2004, 64, 99-107.

[30] Gupta V.K., Jain R., Radhapyari K., Jadon N., Agarwal S., Voltammetric techniques for the assay of pharmaceuticals - A review, Anal. Biochem. 2010, 408, 179-196.

[31] Wilhelm M., Battista H.-J., Obendorf D., Selective and sensitive assay for the determination of benzodiazepines by high-performance liquid chromatography with simultaneous ultraviolet and reductive electrochemical detection at the hanging mercury drop electrode, J. Chromatogr. A, 2000, 897, 215-225.

[32] Wilhelm M., Battista H.-J., Obendorf D., HPLC with simultaneous UV and reductive electrochemical detection at the hanging mercury drop electrode: A highly sensitive and selective tool for the determination of benzodiazepines in forensic samples, J. Anal. Toxicol. 2001, 25, 250-257.

[33] Carvalho L.M.D., Correia D., Garcia S.C., Bairros A.V.D., Nascimento P.C.D., Bohrer D., A new method for the simultaneous determination of 1,4-benzodiazepines and amfepramone as adulterants in phytotherapeutic formulations by voltammetry, Forensic Sci. Int. 2010, 202, 75-81.

[34] Husain S., Prasad P.R., Swamy N.S., Simultaneous quantitative determination of chloral hydrate and diazepam by differential pulse polarography, Indian J. Technol. 1991, 29, 362-363.

[35] Kalvoda R., Kopanica M., Adsorptive stripping voltammetry in trace analysis, Pure \& Appl. Chem., 1989, 61, 97-112.

[36] Al Attas A.S., Construction and analytical application of ion selective bromazepam sensor, Int. J. Electrochem. Sci. 2009, 4, 20-29.

[37] Amorim C.G., Araújo A.N., Montenegro M.C.B.S.M., Silva V.L., Cyclodextrin-based potentiometric sensors for midazolam and diazepam, J. Pharm. Biomed. Anal. 2008, 48, 10641069.

[38] Salem A.A., Barsoum B.N., Izake E.L., Potentiometric determination of diazepam, bromazepam and clonazepam using solid contact ion-selective electrodes, Anal. Chim. Acta 2003, 498, 79-91. 
[39] Salem A.E.A., Barsoum B.N., Saad G.R., Izake E.L., Potentiometric determination of some 1,4benzodiazepines in pharmaceutical preparations and biological samples, J. Electroanal. Chem. 2002, 536, 1-9.

[40] Blankert B., Dominguez O., El Ayyas W., Arcos J., Kauffmann J.-M., Horseradish Peroxidase Electrode for the Analysis of Clozapine, Anal. Lett. 2004, 37, 903-913.

[41] Yu D., Blankert B., Bodoki E., Bollo S., Viré J.-C., Sandulescu R., Nomura A., Kauffmann J.-M., Amperometric biosensor based on horseradish peroxidase-immobilised magnetic microparticles, Sens. Actuator B-Chem. 2006, 113, 749-754.

[42] Özkan S.A., Uska B., Adoul-Enein H.Y., Analysis of pharmaceuticals and biological fluids using modern electrochemical techniques, Crit. Rev. Anal. Chem. 2003, 33, 155-181.

[43] Brooks M.A., The Electrochemical determination of 1,4-benzodiazepines in biological fluids, Bioelectroch. Bioener. 1983, 10, 37-55.

[44] Smyth W.F., Polarography of molecules of biological significance, Academic Press.: London, 1979.

[45] Smyth M.R., Smyth W.F., Voltammetric Methods for the Determination of Foreign Organic Compounds of Biological Significance. A Review, Analyst, 1978, 103, 529-567.

[46] Clifford J.M., Smyth W.F., The Determination of Some 1,4-Benzodiazepines and their Metabolites in Body Fluids. A Review, Analyst, 1974, 99, 241-272.

[47] Trojanowicza M., Recent developments in electrochemical flow detections-A review Part II. Liquid Chromatography, Anal. Chim. Acta, 2011, 688, 8-35.

[48] Mehta A.C. High-pressure liquid chromatographic determination of some 1,4-benzodiazepines and their metabolites in biological fluids :A review, Talanta, 1984, 31, 1-8.

[49] Trojanowicza M., Recent developments in electrochemical flow detections-A review Part I. Flow analysis and capillary electrophoresis, Anal. Chim. Acta, 2009, 653, 36-58.

[50] Flanagan, R.J., Perrett, D., Whelpton, R., (2005). Electrochemical detection in HPLC - analysis of drugs and poisons. Royal Society of Chemistry.

[51] Štulík K., Pacáková V., (1987). Electroanalytical measurements in flowing liquids. Ellis Horwood.

[52] Kissinger P.T. Electrochemical detection in liquid chromatography and flow injection analysis, in Kissinger P.T., Heineman W. R., (ed.) Laboratory techniques in electroanalytical chemistry, Marcel Dekker, New York, 1984 p. 611-635.

[53] Kumar A., Hart J.P., McCalley D.V., Determination of catecholamines in urine using hydrophilic interaction chromatography with electrochemical detection. J. Chromatogr. A 1218 (2011) 38543861.

[54] Martins I., Canaes L.d.S., Doretto K.M., Rath S., Boron-Doped Diamond Electrode Coupled to Liquid Chromatography: Application to Simultaneous Determination of Benzodiazepines, Electroanalysis, 2010, 22, 455-462.

[55] Honeychurch K.C., Smith G.C., Hart J.P., Voltammetric Behavior of Nitrazepam and Its Determination in Serum Using Liquid Chromatography with Redox Mode Dual-Electrode Detection, Anal. Chem. 2006, 78, 416-423.

[56] Honeychurch K.C., Hart J.P., Determination of Flunitrazepam and Nitrazepam in Beverage Samples by Liquid Chromatography with Dual Electrode Detection Using a Carbon Fibre Veil Electrode, J. Solid State Electr. 2008, 12, 1317-1324. 
[57] Saracino M.A., Koukopoulos A., Sani G., Amore M., Raggi M.A., Simultaneous HighPerformance Liquid Chromatographic Determination of Olanzapine and Lamotrigine in Plasma of Bipolar Patients, Ther. Drug Monit. 2007, 29, 773-780.

[58] Kobylińska K., Buś K.M., Bukowska-Kiliszek M., A high-performance liquid chromatography with electrochemical detection for the determination of olanzapine in human plasma, Acta Pol. Pharm. Drug Res. 2008, 65, 759-762.

[59] Honeychurch K.C., Chong A.T., Elamin K., Hart J.P., Novel electrode reactions of diazepam, flunitrazepam and lorazepam and their exploitation in a new redox mode LC-DED assay for serum, Anal. Methods, 2012, 4, 132-140.

[60] Lloyd J.B.F., Parry D.A., Detection and determination of common benzodiazepines and their metabolites in blood samples of forensic science interest: Microcolumn cleanup and highperformance liquid chromatography with reductive electrochemical detection at a pendent mercury drop electrode, J. Chromatogr. A 1988, 449, 281-297.

[61]Lund W., Hannisdal M., Greibrokk T., Evaluation of Amperometric Detectors for HighPerformance Liquid Chromatography: Analysis of Benzodiazepines, J. Chromatogr. A, 1979, 173, 249-261.

[62] Hackman M.R., Brooks M.R., Differential pulse amperometric detection of drugs in plasma using a dropping mercury electrode as a high performance liquid chromatographic detector, J. Chromatrogr. 1981, 222, 179-190.

[63] Lurie I.S., Cooper D.A., Klein R.F.X., High-performance liquid chromatographic analysis of benzodiazepines using diode array, electrochemical and thermospray mass spectrometric detection, J. Chromatogr. 1992, 598, 59-66.

[64] Catlow J.T., Barton R.D., Clemens M., Gillespie T.A., Goodwin M., Swanson S.P., Analysis of olanzapine in human plasma utilizing reversed phase high-performance liquid chromatography with electrochemical detection, J. Chromatogr. B, 1995, 668, 85-90.

[65] Aravagiri M., Ames D., Wirshing W.C., Marder S.R., Plasma Level Monitoring of Olanzapine in Patients With Schizophrenia: Determination by High-Performance Liquid Chromatography With Electrochemical Detection, Ther. Drug Monit. 1997, 19, 307-313.

[66] Raggi M.A., Casamenti G., Mandrioli R., Volterra V., A sensitive high-performance liquid chromatographic method using electrochemical detection for the analysis of olanzapine and desmethylolanzapine in plasma of schizophrenic patients using a new solid-phase extraction procedure, J. Chromatogr. B, 2001, 750, 137-146.

[67] Kasper S.C., Mattiuz E.L., Swanson S.P., Chiu J.A., Johnson J.T., Garner C.O., Determination of olanzapine in human breast milk by high-performance liquid chromatography with electrochemical detection, J. Chromatogr. B, 1999, 726, 203-209.

[68] Bao J., Potts B.D., Quantitative determination of olanzapine in rat brain tissue by high performance liquid chromatography with electrochemical detection, J. Chromatogr. B, 2001, 752, 61-67.

[69] Kakizaki T., Hasebe K., Yoshida H., Konishi G., Improvement for signal-to-noise ratio of polarographic detector in liquid chromatography, Anal. Sci. 1987, 3, 469-417.

[70] Hanekamp H.B., Voogt W.H., Frel R.W., Bos P., Continuous flow alternating current polarographic detection of nitrazepam in liquid chromatography, Anal. Chem. 1981, 53, 13621365. 
[71] Rodriguez I.B., Procopio J.R., Hernandez L.H., Determination of Clotiazepam by HPLC with spectrophotometric and amperometric detection, Fresenius J. Anal. Chem. 1987, 328, 117-119.

[72] Chiu J.A., Franklin R.B., Analysis and pharmacokinetics of olanzapine (LY170053) and two metabolites in rat plasma using reversed-phase HPLC with electrochemical detection, J. Pharm. Biomed. Anal. 1996, 14, 609-615.

[73] Li W.B., Zhai Y.M., Wang C.Y., Qin Y.F., Weng Y.Z., Study of the detection characteristics of for clozapine, $\mathrm{N}$-desmethylclozapine, olanzapine and olanzapine with high performance liquid chromatography-electrochemical detector, $\mathrm{Se} \mathrm{Pu,} \mathrm{2000,} \mathrm{18,} \mathrm{550-553.} \mathrm{(Abstract} \mathrm{only,} \mathrm{in} \mathrm{Chinese).}$

[74] Raggi M.A., Casamenti G., Mandrioli R., Fanali S., De Ronchi D., Volterra V., Determination of the novel antipsychotic drug olabzapine in human plasma using HPLC with amperometric detection, Chromatographia, 2000, 51, 562-566.

[75] Das S., Fisher E., Grever T., Burras B., Freiser H., Increased assay robustness and throughput using automated 96-well solid phase extraction, Asian Journal of Drug Metabolism and Pharmacokinetics, 2004, 4, 97-100.

[76] Saracino M.A., Gandolfi O., Dall'Olio R., Albers L., Kenndler E., Raggi M.A., Determination of Olanzapine in rat brain using liquid chromatography with coulometric detection and a rapid solidphase extraction procedure, J. Chromatogr. A, 2006, 1122, 21-27.

[77] Baumann A., Lohmann W., Schubert B., Oberacher H., Karst U., Metabolic studies of tetrazepam based on electrochemical simulation in comparison to in vivo and in vitro methods, J. Chromatogr. A, 2009, 1216, 3192-3198.

[78] Mouithys-Mickalad A., Kauffmann J.-M., Petit C., Bruhwyler J., Liao Y., Wikstrom H., Damas J., Delarge J., Deby-Dupont G., Geczy J., Liegeois J.-F., Electrooxidation Potential as a tool in the early screening for new safer clozapine-like analogues, J. Med. Chem. 2001, 44, 769-776.

(C) 2014 by the authors; licensee Insciences Journal.

Open Access article under the terms and conditions of Creative Commons Attribution Non-Commercial License 3.0 Unported. 